\title{
Airborne pollen spectrum and hay fever type prevalence in Vinnitsa, central Ukraine
}

\author{
Victoria Valeriivna Rodinkova* \\ Vinnitsa National Pirogov Memorial Medical University, Department of Pharmacy, Pirogov 56, Vinnitsa 21018, Ukraine
}

\begin{abstract}
The article deals with the main pollen spectrum in relation to patients' sensitivity determined in the ambient air of Vinnitsa city located in central Ukraine. The study performed by gravimetric sampling in the years 1999-2000 and by volumetric sampling in the years 2009-2014 showed that Urtica, Betula, Pinus, Alnus, Fraxinus, Ambrosia, Artemisia, Juglans, Carpinus, Populus, Quercus, Acer, Salix, Poaceae, Amarathaceae, and Polygonaceae pollen grains are prevalent among the airborne allergen types in the urban atmosphere. The principal pollen types remain the same but over time their quantities have changed. The relative abundance of Carpinus and Amaranthaceae airborne pollen decreased while the fraction of Urtica pollen increased in the last decade. From 50 to 69 pollen types were determined in the ambient air depending on the season. From 24 to 27 pollen types represented woody plants and from 22 to 46 pollen types belonged to the herbaceous plants. A considerable decrease in herbal pollen types is noted in the Vinnitsa air at present.

It was shown that children were sensitive to weed pollen grains, including ragweed, mugwort, and grass, while adults were more sensitive to tree and grass pollen grains. Further studies of the pollen spectrum in the ambient air of this city are required in order to control the hay fever symptoms.
\end{abstract}

Keywords: aerobiology; airborne pollen spectrum; pollen sensitivity; Ukraine

\section{Introduction}

Allergy affects $20 \%$ of the European population - or more than 150 million people - thus making it the most frequent chronic complaint [1]. The sufferers have to struggle daily with debilitating effects of their condition including a risk of an asthma attack or anaphylactic shock [2]. It is estimated that 1 in 2 Europeans from all strata of society are expected to suffer from allergy symptoms by 2025 if the allergy epidemic is not checked by the joint action of policy makers as well as medical care specialists [3]. Furthermore, allergy imposes a significant social and economic burden on EU citizens and health systems. The avoidable indirect costs of failure to treat allergy properly in the EU are estimated to be between 55 and 151 billion Euro per annum.

Nasal allergies are the most common allergy type and the prevalence of these allergies is increasing, affecting as many as $30 \%$ of adults and $40 \%$ of children [4]. There are no sufficient cures for allergies. They can be managed only with proper prevention or applying treatments that effectively control symptoms [5]. That is why the problem of allergy prevention, e.g., avoidance of contact with the

\footnotetext{
*Email: vikarodi@gmail.com
}

Handling Editor: Agnieszka Grinn-Gofroń allergen, is one of the most important challenges for the allergy healthcare [4].

One of the most common causes of allergy is the Betula, Alnus, Poaceae, Ambrosia, Artemisia, and Plantago pollen grains. These harmless environmental molecules are mistaken for parasites, and the immune system elicits a strong Th2 and IgE-driven response that fails to remove these "irrelevant threats", yet does induce the clinical symptoms of rhinorrhoea, nasal congestion, and itching [6]. There are a few other pollen types responsible for provocation of symptoms. Tree, weed, and grass pollen are among them, including alder, ash, oak, dandelion, mugwort, and ragweed pollen grains.

Investigations show that the allergic symptoms are likely to worsen in the future because of climate change. This happens while air pollution increases the allergenicity of pollen, raises its impact on the human body, and extends the pollination period [7]. Pollen of invasive species, which is not common for the pollen spectrum of a native population area, is another important factor of pollen-provoked allergy symptoms [8]. While climate and flora change gradually in different regions, it is important to know the exact species provoking allergy symptoms in a certain area at a certain time. In order to control pollen allergy symptoms, it is necessary to study the pollen spectra specific to a given region throughout the pollen season. 
Thus, the aim of the investigation was to establish the main pollen spectrum of ambient air of Vinnitsa city located in central Ukraine in relation to patients' sensitivity.

\section{Material and methods}

Pollen counts from 1999 to 2000 were obtained by gravimetric sampling with three Durham traps placed on roofs in different districts of Vinnitsa city. The pollen collection was done by volumetric sampling employing a Burkard trap placed at a height of 25 meters above the ground on the roof of the Vinnitsa National Medical University building in the years 2009-2014. Samples were taken from March 1 until October 31 in all the years when the study was conducted. The pollen count was performed by the reading of a $3.24 \mathrm{~cm}^{2}$ area (the total area of the coverslip) after pollen acetolysis in the years 1999-2000, by the three horizontal transect method in the years 2009-2011, and by the twelve vertical transect method in the years 2012-2014. The maximum distance between the site locations was $3.9 \mathrm{~km}$, and the minimum was $2.37 \mathrm{~km}$ (Tab. 1).

The mean daily pollen count data was used for analyses of the airborne pollen spectrum in the years 2009-2014. The pollen quantity per $\mathrm{cm}^{2}$, average for the three sites, was used in the years 1999-2000. Pollen grains were identified using the pollen reference slides of Ukraine, the pollen identification key program [9], and the pollen atlas edited by the American National Aerobiology Bureau [10].

Symptoms of seasonal allergy were analyzed by reviewing the medical records from allergy clinics at the Vinnitsa Regional Clinical Children Hospital and at Vinnitsa Municipal Hospital Number 1, Vinnitsa, Ukraine. Records of 38 patients aged from 3 to 16 were reviewed with 20 selected for further analysis from among the children admitted from 2004 to 2013. Thirty-eight patients aged 18 to 45 were selected for analysis in the Municipal Hospital as well. Prick tests for inhalant pollen grains were done using extracts made in Ukraine. The results of 50 separate clinical tests of children and 38 tests of adults in the study group were analyzed.

\section{Results}

The study showed the annual prevalence of stinging nettle (Urtica) pollen and tree pollen in the ambient air of Vinnitsa city. Birch (Betula), pine tree (Pinus), alder (Alnus), and ash (Fraxinus) pollen grains were predominant among those produced by trees. The top-20 list of dominating pollen types included Ambrosia, Poaceae, Artemisia, Juglans, Carpinus, Populus, Quercus, Acer, Salix, Ulmus, and hazel Corylus pollen grains as well as pollen grains of Amarathaceae, Polygonaceae including Rumex, Asteraceae, Brassicaceae, Ranunculaceae, and Cannabaceae plant families. The percent of Carpinus and Amaranthaceae airborne pollen count decreased in comparison with the years 1999 and 2000. The taxa most frequently included in the top-10 pollen list were Poaceae, Ambrosia, and Artemisia pollen grains recorded in high quantities in every year of the observation. Thus, Poaceae pollen fluctuated from the 3 rd to the 8 th position on the top-10 with its highest level in the year 2009 and the lowest in the year 2000. Artemisia pollen held positions from the 4th to 7 th on the top-10 with the highest level in the years 2009, 2012, 2013 and the lowest in the years 1999 and 2014. Ambrosia pollen levels fluctuated in a wide range with at the highest values (second position) recorded in the year 2011 and at the lowest (the 10th) in the year 2000.

Betula and Alnus pollen grains were recorded among the most abundant pollen types in 7 of the 8 years of observation. Betula held the first or the second position on the list for 6 out of the 8 years. It dropped to the sixth position only in the year 2009. Alnus pollen held from the 3rd to 9th positions on the top-10 of pollen types of the ambient air of Vinnitsa city, with even greater abundance in the years 2010, 2012, and 2014. Alnus pollen reached in the 3 rd position in these seasons.

Urtica pollen was the leader of the last few years, as it was recorded in the first position of abundance in the years 2009-2013 and in the second position in the year 2014 .

Juglans pollen was ranked in the top- 10 in 6 out of the 8 years of observations. On the top-20 pollen taxa list in the years 1999 and 2010, Juglans pollen was recorded in positions 6 to 9 in the years $2000,2009,2011-2014$.

Tab. 1 Pollen trap locations; counting and sampling methods in the different years of investigation, Vinnitsa, central Ukraine.

\begin{tabular}{|c|c|c|c|c|c|c|c|}
\hline No. & Location name & $\begin{array}{l}\text { Location } \\
\text { latitude } \\
{ }^{\circ} \mathrm{N}\end{array}$ & $\begin{array}{l}\text { Location } \\
\text { longitude } \\
{ }^{\circ} \mathrm{E}\end{array}$ & $\begin{array}{l}\text { Location } \\
\text { altitude above } \\
\text { the ground, } m\end{array}$ & $\begin{array}{l}\text { Distance to } \\
\text { location No. } \\
4, \mathrm{~km}\end{array}$ & $\begin{array}{l}\text { Sampling } \\
\text { method }\end{array}$ & Counting method \\
\hline 1 & $\begin{array}{l}\text { Kelets'ka street, } 118 \text {, } \\
\text { multistory building }\end{array}$ & 49.23 & 28.40 & 30.00 & 3.32 & Gravimetric & $\begin{array}{l}\text { Count on } 3.24 \mathrm{~cm}^{2} \text { area after } \\
\text { pollen acetolysis }\end{array}$ \\
\hline 2 & $\begin{array}{l}\text { VSPU*, Ostroz'ky street, } \\
32\end{array}$ & 49.24 & 28.50 & 30.00 & 3.90 & Gravimetric & $\begin{array}{l}\text { Count on } 3.24 \mathrm{~cm}^{2} \text { area after } \\
\text { pollen acetolysis }\end{array}$ \\
\hline 3 & $\begin{array}{l}\text { Vinnitsa Municipal } \\
\text { Hospital No 3, Maiakovsky } \\
\text { str., } 138\end{array}$ & 49.21 & 28.47 & 18.00 & 2.37 & Gravimetric & $\begin{array}{l}\text { Count on } 3.24 \mathrm{~cm}^{2} \text { area after } \\
\text { pollen acetolysis }\end{array}$ \\
\hline 4 & $\begin{array}{l}\text { VNMU*, Pirogov street, } \\
56\end{array}$ & 49.23 & 28.44 & 25.00 & 0.00 & Volumetric & $\begin{array}{l}\text { 2009-2011 - longitudinal, } \\
\text { 2012-2013 - vertical transects }\end{array}$ \\
\hline
\end{tabular}

* Note: VSPU - Vinnitsa State Pedagogical University; VNMU - Vinnitsa National Medical University. 


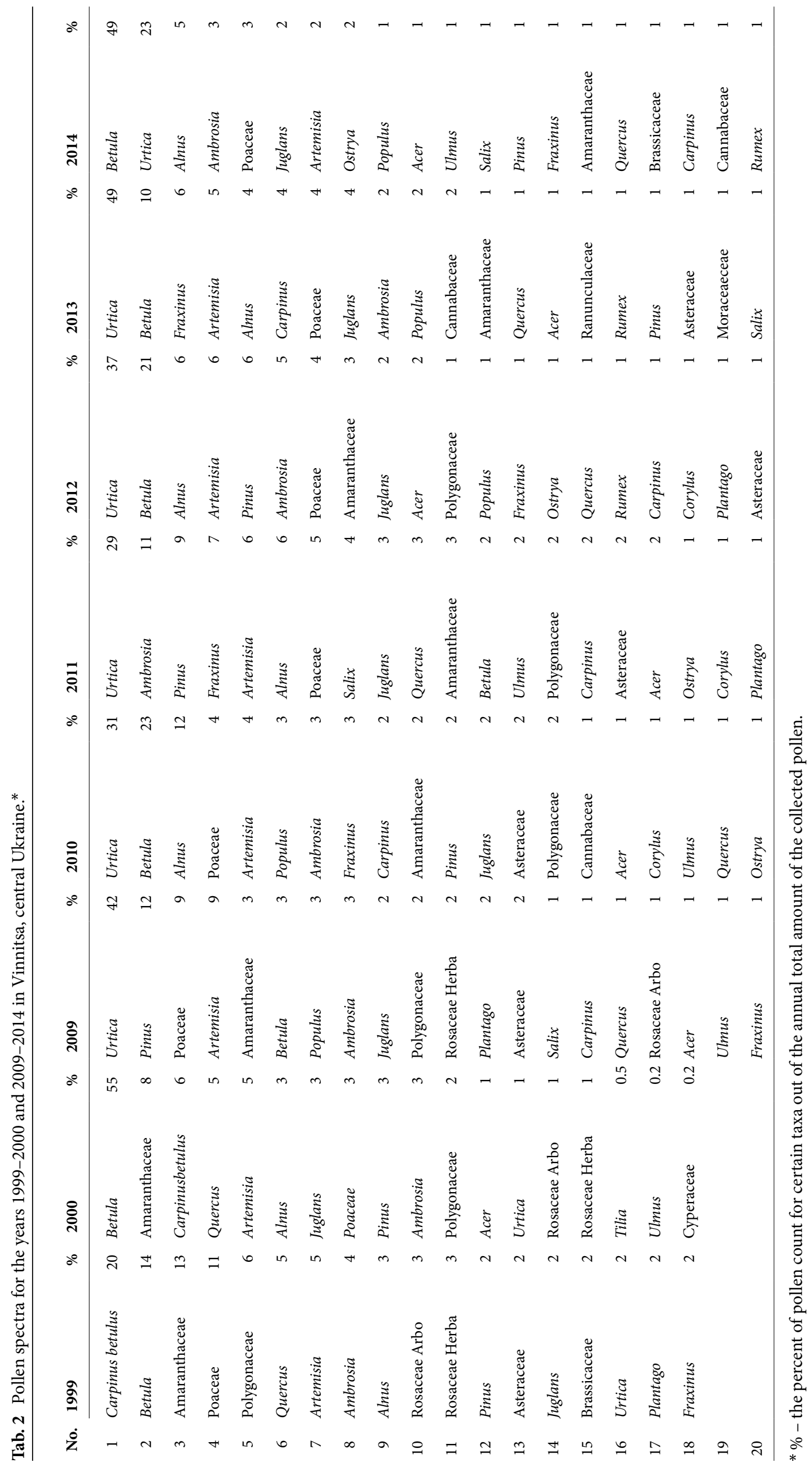


Amaranthaceae pollen was recorded on the top-10 pollen taxa list only in 5 out of the 8 years. Carpinus, Populus, and Pinus pollen types were included in top-10 four times.

Quercus and Fraxinus pollen reached the top-10 three times and was mostly recorded in the lower half of the top-20 list. Over time, Polygonaceae pollen lost its high position in the pollen spectrum, which it held in the year 1999 when it was recorded twice on the top-10 list. Rosaceae pollen was present on the top-10 pollen types list only in the year 1999 (Tab. 2).

Similarly to Polygonaceae, Acer pollen was ranked in the lowest position of the top-10 only twice. Rosaceae, Salix, and Ostrya pollen types were included on the top-10 pollen taxa list only once.

While comparing the abundance of the arboreal and herbal pollen in the ambient air, it was established that the highest levels of tree pollen were recorded in the years 2000 and 2014 with the tree pollen portion of $77 \%$ and $63 \%$, correspondingly (Fig. 1).

The high tree pollen count was definitely associated with the unusually abundant Betula pollination recorded in Vinnitsa in those years (Tab. 2). The other seasons were characterized by a lower amount of tree pollen fluctuating within $32-50 \%$. The number of tree taxa was usually lower than the number of herbal ones contributing to the annual pollen rain of Vinnitsa city. The highest number of herbal pollen types was seen in the years 1999 and 2000 (45 and 46 respectively), while the lowest was by half lower and was recorded in the years 2013 and 2014 (22 and 23, respectively). The number of pollen of woody plants fluctuated from 22 to 27 in all the years of the observation (Fig. 1).

Since different methods were applied, we compared the total annual pollen count only for the years 2009-2014 when the volumetric sampling was performed. The lowest total annual pollen count was recorded for the year 2009. The highest pollen load was associated with the years 2010 and 2014. The Betula pollen count was high in these years as well. The year 2010 was characterized by unusually abundant
Alnus pollination, which also contributed to the increased amount of pollen in Vinnitsa. There was a significant 2.5-fold difference between the highest and lowest annual total values of the collected pollen. It was around 19000 particles versus 50000 particles for the years 2009 and 2014, respectively (Fig. 2).

There were two principal periods of the increase in the pollen concentration in Vinnitsa. They were related to tree pollination with an intensive period of particle emission in April. Pollen peaks occurred commonly in late April in this case and were associated with birch, hornbeam, and ash pollination. The year 2014 was characterized by unusually early birch pollination with a peak occurring in early April.

The second pollen concentration increase was reported from mid-June until the end of August. It was related to Urtica, Ambrosia, and Artemisia pollination. The peaks were associated with Urtica pollen release in early July. The Urtica pollen concentrations were high until the end of August,

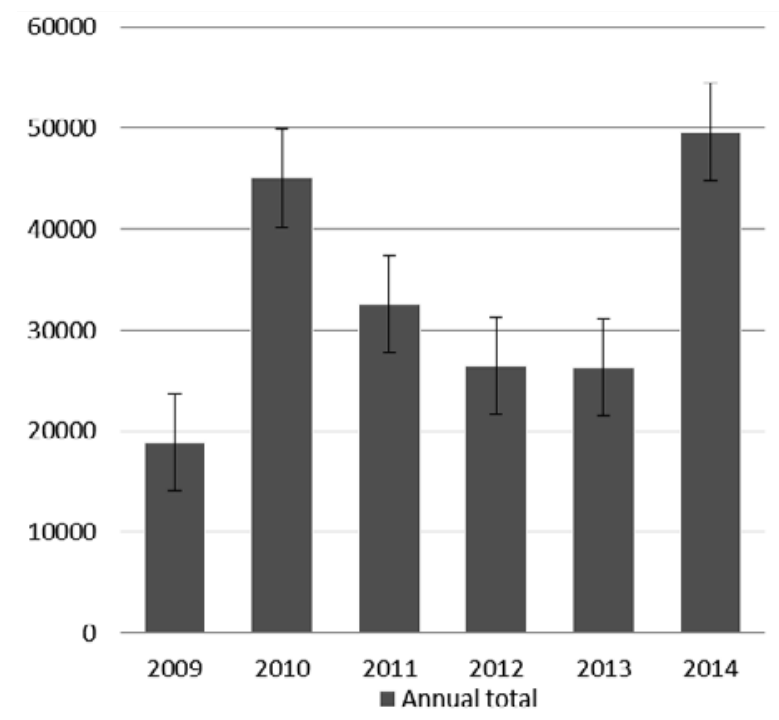

Fig. 2 Total annual pollen load in the ambient air of Vinnitsa city, central Ukraine, in 2009-2014. Means and standard errors are given.

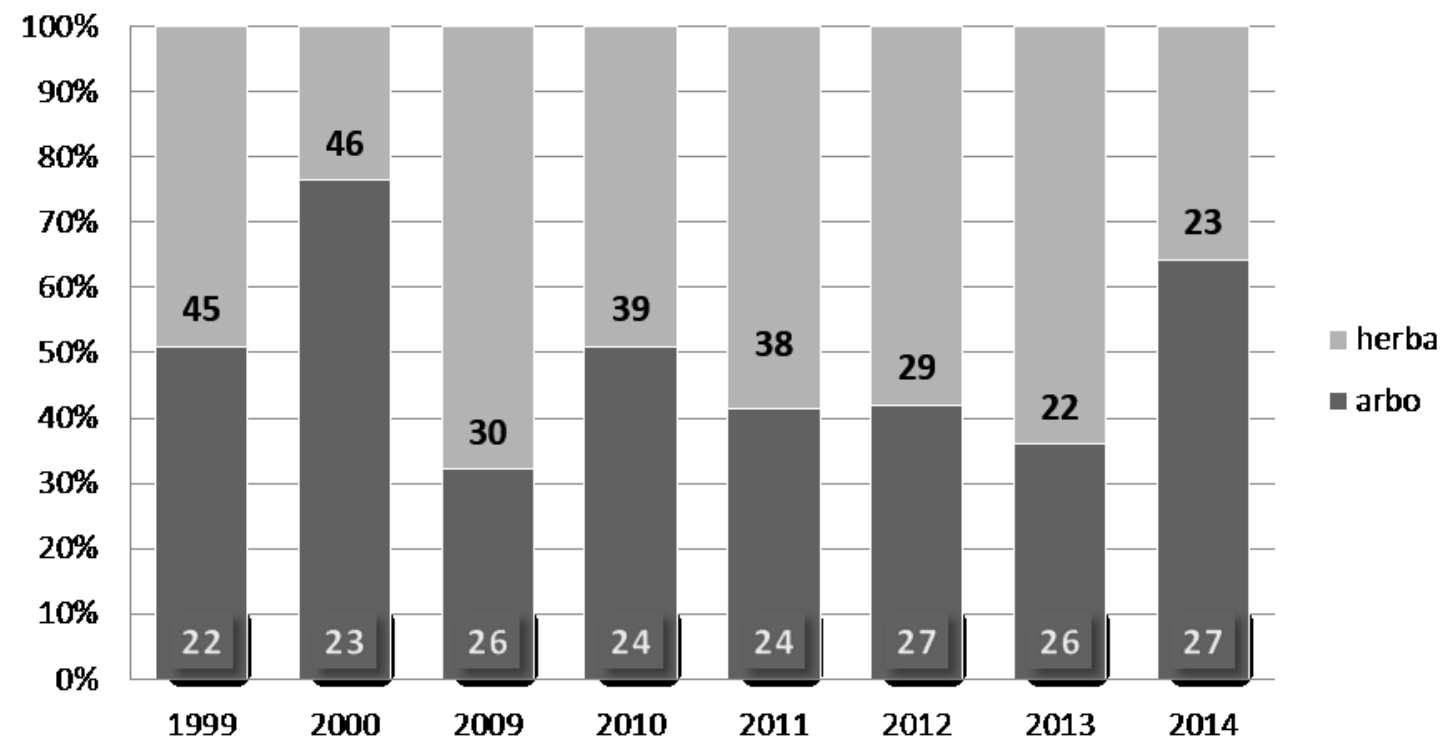

Fig. 1 The ratio of arboreal and herbal pollen grains and the number of corresponding taxa in the pollen spectra in Vinnitsa in 1999-2000 and 2009-2014. 
usually exceeding the Artemisia peak in the first ten days of August. The Ambrosia peak came last, generally completing the pollen season in late August or in the first 2-3 weeks of September. It was established that the pollen load increase was associated with the mean daily temperature in Vinnitsa in September [11].

Grass pollen, which is considered an important allergen, was noted in the ambient air from the beginning of May until mid-July. The most intensive Poaceae pollination was recorded in late June and early July (Fig. 3).

Medical records of Vinnitsa Municipal Hospital No. 1 and of the Vinnitsa Regional Children Hospital were analyzed to establish the pollen impact on patients' health. While analyzing the patients' medical records obtained in the Children Hospital, it was established that 17 (85\%) of the young patients were males who lived in rural areas and only three of them were residents of Vinnitsa. Two of the three infants were referred to allergy testing at the age from 1 to 5 . They were also tested repeatedly during the period between ages 6 and 10. The maximum number of hospital tests performed on one patient was 5. It was noted that the symptoms appeared mostly in children from 6 to 10 years of age. $13(65 \%)$ of the children were tested at this age for the first time. The sensitization to pollen was significantly more pronounced than the susceptibility to other types of allergens in children aged 6 to 16. Ragweed and sunflower allergens were the leading causal agents for allergy symptoms for children aged 3 to 5 (the patients showed very high sensitivity). Reaction to Poaceae allergens showed mild sensitivity.
In contrast, children from 6 to 10 years of age were sensitized mostly to grasses (Festuca, Phleum, Poa). The sensitivity to ragweed and sunflower pollen varied from mild to very high ( 2 observations of 6 ). The sensitivity to tree pollen was at a low level. A moderate reaction to alder and hazel allergens was noted in three of the Vinnitsa residents. The recorded birch and hornbeam allergy in one of those children was at a low level. However, there was either no or very low reaction to grass or weed allergens (despite the fact that both of these plant categories are just as widely spread).

The reaction to tree pollen grains became prominent in patients from rural areas aged over 11. At this age, the children became moderately and highly sensitive to birch, alder, and hazel pollen grains. However, the sensitivity to grass and weed pollen was more severe than the allergic reaction to tree pollen. Besides the very high sensitivity to grass allergens mentioned above, the children showed moderate susceptibility to mugwort and sunflower and moderate to very high sensitivity to dandelion and ragweed allergens. The sensitivity to birch and alder pollen grains was predominant in the adult patient group. Alnus and Betula pollen grains were determined as the main pollen type for adult patient's sensitivity. Of the 36 patients who underwent the testing, 33 (80\%) had an acute reaction to Alnus pollen, even to 1:1 000000 dilution of the allergen. Betula and Carpinus pollen grains showed the second and third levels of sensitivity in the adult patients ( $72 \%$ and $60 \%$ of patients, respectively, were sensitive to these pollen types). The sensitivity to the hazel pollen recorded in the top-20 of the pollen spectra

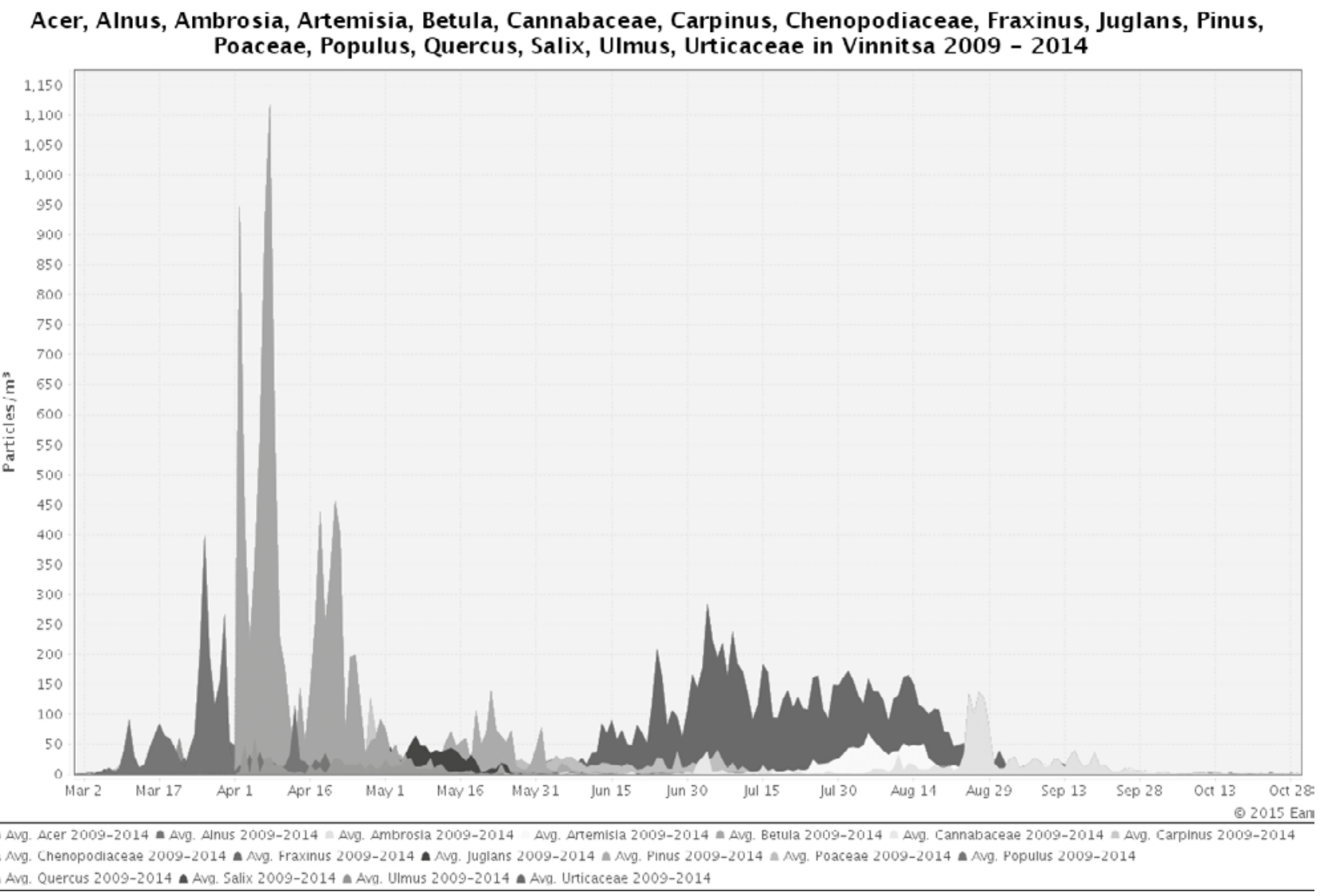

Fig. 3 The timing and intensity of pollen emission by main taxa in Vinnitsa, central Ukraine, average from 2009-2014 
in the years 2010 and 2011 was unexpectedly high. $40 \%$ of the examined patients were sensitive to this pollen. $10 \%$ of the volunteers demonstrated sensitivity to oak pollen. The sensitivity to maple, poplar, ash, willow, and walnut pollen grains was weakly manifested in another study [12].

\section{Discussion}

The study shows that Urtica, Betula, Pinus, Alnus, Ambrosia, Artemisia, Juglans, Carpinus, Populus, Quercus, Fraxinus, Acer, Poaceae, and Amarathaceae are the main airborne pollen types in the urban atmosphere of Vinnitsa city. These airborne pollen taxa are typical for the temperate zone of Europe [13]. Thus, pollen grains of Alnus, Ambrosia, Betula, Carpinus, Corylus, Poaceae, Urticaceae, and Artemisia were found to be the most abundant in Croatia [14]. Eight pollen taxa from the top-10 pollen taxa list discussed above are represented on the list of 12 most allergenic pollen types in Europe. They are included on the list of allergic pollens of primary importance established for Europe by Sofiev and Bergmann [15]. These taxa are namely Alnus, Ambrosia, Artemisia, Betula, Amaranthaceae, Poaceae, Quercus, Urtica pollens found in high quantity in the ambient air of Vinnitsa city.

Fluctuations of pollen counts of certain taxa in different pollen seasons may be related to the weather conditions and to the internal biological rhythms of plants [15-18]. Thus, Betula and Alnus pollen types were recorded at the second and third positions, respectively, in the annual pollen spectra of Vinnitsa city in the years 2010, 2012, and 2014. The increase in pollination intensity every other year might be related to the internal biennial biorhythm of these plants [19].

The pollen load increase in the year 2014 might be explained by the warming impact, which promotes more intense and extended plant pollination [20]. The tendency to increase observed in the herbal flora portion of the pollen spectrum of Vinnitsa city might be related to the climate change as well [21]. The considerable decrease in the number of herbal pollen taxa in the pollen count recorded at present in comparison with the years 1999-2000 might also be related to the climate change and may indicate decreased plant biodiversity in the Vinnitsa area.

The significant presence of the tree pollen grains in the ambient air of Vinnitsa city is accounted for by the geographical location of Vinnitsa in the forest-steppe zone of Ukraine. Nevertheless, it has been shown that Urtica pollen is prevalent in the air of the city. However, the pollen of the stinging nettle is not present on the list of the regional causal allergens due to its low allergenicity proved by the studies [15]. Ambrosia and Artemisia pollen grains are more allergic for children, while allergy symptoms caused by tree pollen grains such as Betula and Alnus are more manifested among the adult population of Vinnitsa. From the early childhood, the children from rural areas of central Ukraine were much more susceptible to grass and weeds allergens than to those produced by trees. This phenomenon might be associated with the short height of very young children and, thus, their higher exposure to grasses and weeds. The fact that grass pollen affects children more than birch pollen was shown in Sweden [22]. The male gender of the pollen-sensitized children patients in Vinnitsa corresponds with data from other studies as well, showing that boys are more susceptible to pollen allergens than girls [15].

Even though the severity of sensitization to tree pollen increases throughout the lifetime of Ukrainian patients, the reaction to grass and weed allergens remains at high and very high levels in these patients. The high pollen peak and considerable alder particle load recorded for this specie in the ambient air of Vinnitsa city in the years 2010, 2012, and 2014 might explain the patients' acute reaction to Alnus pollen. The alder pollination peak, which now occurs up to a month earlier than 10 years ago, might be noted as an important time of appearance of hay fever symptoms in Vinnitsa inhabitants as well.

The hazel pollen count was relatively low (Tab. 1) and the high reactivity to this pollen type might be explained by the cross-reactions of pollen grains within Betulaceae Family including birch, hornbeam, and hazel plants [23].

Thus, the data of airborne pollen monitoring is of great importance for hay fever control due to the modification of plant pollination patterns related to the climate change.

\section{Conclusions}

Urtica, Betula, Alnus, Ambrosia, Artemisia, Carpinus, Juglans, Quercus, Amaranthaceae, and Poaceae are the most frequent pollen types on the top-10 pollen list recorded in the ambient air of Vinnitsa, central Ukraine. All of them are represented on the list of most allergenic European pollen types.

The significant presence of the tree pollen grains in the ambient air of Vinnitsa city is accounted for by the geographical location of Vinnitsa in the forest-steppe zone of Ukraine. However, a tendency to increase was observed in the herbal flora portion of the pollen spectrum of Vinnitsa city. There is a considerable decrease in the number of herbal pollen taxa in the pollen count at present, in comparison with the years 1999-2000.

Fluctuations of pollen counts of certain taxa in different pollen seasons may be related to the weather conditions and to the internal biological rhythms of the plants, including the internal biennial biorhythm of Betula and Alnus. The change in the contribution of the pollen types to the annual total recorded throughout the years of investigation might be related to climate change.

Children were sensitive to the weed pollen grains, including ragweed, mugwort, and grass, while adults were more sensitive to tree pollen. Although the severity of sensitization to tree pollen increases throughout the lifetime of Ukrainian patients, the reaction to grass and weed allergens remains at high and very high levels in these patients.

The high reactivity to Corylus pollen might be explained by the cross-reactions of pollen grains within Betulaceae family representatives, including birch, hornbeam, and hazel plants. 


\section{Acknowledgments}

The author would like to thank Natalie Yarmilko for the design of the Fig. 3, the administrations of both Vinnitsa Municipal Hospital No. 1 and the Vinnitsa Regional Children Hospital for the medical data records provided for the analyses, and also Aliona Dratsion for editing this article. The study was done within the scientific plan of Vinnitsa National Pirogov Memorial Medical University by funds received from University as a salary.

\section{Competing interests}

No competing interests have been declared.

\section{References}

1. European Academy of Allergy and Clinical Immunology (EAACI) [Internet]. Advocacy manifesto "Tackling the allergy crisis in Europe"concerted policy action needed. 2014 [cited 2015 Sep 15]; Available from: http://www.eaaci.org/images/resources/fellowships/awardees/ EAACI-Advocacy-manifesto-Nov2014.pdf

2. Valovirta E, editor. EFA book on respiratory allergies: raise awareness, relieve the burden. Brussels: European Federation of Allergy and Airways Diseases Patients Associations; 2011.

3. European Academy of Allergy and Clinical Immunology (EAACI) [Internet]. Stronger together: collaboration at policy level to tackle the allergy epidemic in Europe. 2015 [cited 2015 Sep 15]; Available from: http://www.eaaci2015.com/wp-content/uploads/2014/05/ Press-Release_Stonger-Together-Collaboration-at-policy-level-totackle-the-allergy-epidemic_-EAACI-Congress2015_Final1.pdf

4. American College of Allergy, Asthma, and Immunology [Internet]. Allergy facts. 2014 [cited 2015 Oct 10]; Available from: http://acaai. org/news/facts-statistics/allergies

5. Asthma and Allergy Foundation of America [Internet]. Allergy facts and figures. 2015 [cited 2015 Oct 10]; Available from: http://www. aafa.org/display.cfm?id $=9 \& \mathrm{sub}=30$

6. Akdis CA, Hellings PW, Agache I, editors. Global atlas of allergic rhinitis and chronic rhinosinusitis. Zurich: European Academy of Allergy and Clinical Immunology; 2015.

7. European Academy of Allergy and Clinical Immunology (EAACI) [Internet]. More Europeans will be allergic to pollen if measure is taken to reduce exposure. 2015 [cited 2015 Sep 15]; Available from: http://eaaci.org/images/EAACI_-_EAS_-_EFA_-_IRS_Joint_PR_-_International_Ragweed_Day_2015.pdf

8. Thibaudon M. Pollen: a biological pollutant? International Aerobiology Newsletter. 2013,75(1):1.

9. Sulmont G, Reseau National de Surveillance Aerobiologique, editors. The pollen content of the air: identification key [CD-ROM]. SaintÉtienne: Studio Bouquet; 2008.

10. Kagen S, Lewis WH, Levetin E. The classic collection transcribed. Aeroallergen photolibrary of North America. Appleton, WI: DePass Media Productions; 2004-2005.

11. Rodinkova V, Palamarchuk O, Motruk I, Kremenska L, Musatova K. Temperature increase stimulates early and extended ragweed flowering in Ukraine. In: Proceedings of the EAN EAS symposium 2014; 2014 Nov 10-11; Vienna, Austria. Vienna: Medical University of Vienna; 2014. p. 15-16.

12. Rodinkova V, Stremedlovsky B, Kremenska L, Palamarchuk O, Bilous $\mathrm{O}$, DuBuske L, et al. Correlation between the airborne pollen counts and symptoms of allergic patients in Vinnitsa, Ukraine. Allergy. 2012;67(96 suppl):249.

13. Peternel R, Culig G, Miti B, Hrga I, Vukuši I. Airborne pollen spectra at three sites in inland Croatia. Bot Bull Acad Sin. 2005;46:53-59.
14. Smith M, Jäger S, Berger U, Šikoparija B, Hallsdottir M, Sauliene I, et al. Geographic and temporal variations in pollen exposure across Europe. Allergy. 2014;69(7):913-923. http://dx.doi.org/10.1111/all.12419

15. Sofiev M, Bergmann KC, editors. Allergenic pollen: a review of the production, release, distribution and health impacts. Dordrecht: Springer; 2013. http://dx.doi.org/10.1007/978-94-007-4881-1

16. Piotrowska-Weryszko K, Weryszko-Chmielewska E. The airborne pollen calendar for Lublin, central eastern Poland. Ann Agric Environ Med. 2014;21(3):541-545. http://dx.doi.org/10.5604/12321966.1120598

17. Rodriguez-Rajo FJ, Dopazo A, Jato V. Environmental factors affecting the start of pollen season and concentrations of airborne Alnus pollen in two localities of Galicia (NW Spain). Ann Agric Environ Med. 2004;11(1):35-44.

18. Piotrowska K, Kubik-Komar A. The effect of meteorological factors on airborne Betula pollen concentrations in Lublin (Poland). Aerobiologia (Bologna). 2012;28(4):467-479. http://dx.doi.org/10.1007/ s10453-012-9249-z

19. Rodinkova VV, Slododianiuk LV, Motruk II, Mazur OI, Kremenska LV, DuBuske LM. High Betula pollen counts occur during even years in Ukraine. Allergy. 2014;69(99 suppl):435.

20. D’Amato G, Baena-Cagnani CE, Cecchi L, Annesi-Maesano I, Nunes C, Ansotegui I, et al. Climate change, air pollution and extreme events leading to increasing prevalence of allergic respiratory diseases. Multidiscip Respir Med. 2013;8:12. http://dx.doi. org/10.1186/2049-6958-8-12

21. Ariano R, Canonica G, Passalacqua G. The possible role of climate changes in variation of pollen seasons and allergic sensitization over 27 years. Allergy. 2010:65(92):425. http://dx.doi.org/10.1016/j. jaci.2009.12.753

22. Gruzieva O, Pershagen G, Wickman M, Melén E, Hallberg J, Bellander T, Lõhmus M. Exposure to grass pollen - but not birch pollen - affects lung function in Swedish children. Allergy. 2015;70(9):1181-1183. http://dx.doi.org/10.1111/all.12653

23. European Aeroallergen Network [Internet]. 2015 [cited 2015 Sep 15]; Available from: https://ean.polleninfo.eu/Ean

\section{Spektrum pyłkowe powietrza a częstość występowania kataru siennego w Winnicy w centralnej Ukrainie}

\section{Streszczenie}

W pracy przedstawiono spektrum pyłku alergicznego stwierdzanego w powietrzu miasta Winnica położonego w centralnej części Ukrainy, w powiązaniu $\mathrm{z}$ wrażliwością pacjentów. Badania przeprowadzone metodą grawimetryczną w latach 1999-2000 i wolumetryczną w latach 2009-2014 wykazały, że ziarna pyłku Urtica, Betula, Pinus, Alnus, Fraxinus, Ambrosia, Artemisia, Juglans, Carpinus, Populus, Quercus, Acer, Salix, Poaceae, Amarathaceae, oraz Polygonaceae są alergenami występującymi powszechnie w powietrzu atmosferycznym miasta. Na przestrzeni lat badań stwierdzono podobne rodzaje pyłku w spektrach sezonowych, ale wystąpiła znaczna zmienność ilościowa. Względna obfitość pyłku Carpinus i Amaranthaceae w powietrzu zmniejszała się, natomiast frakcja pyłku Urtica zwiększała się w ciągu ostatniej dekady. Oznaczano od 50 do 69 typów pyłku w powietrzu w zależności od sezonu. Rośliny drzewiaste reprezentowało od 24 do 27 rodzajów pyłku, a 22 do 46 rodzajów pochodziło od roślin zielnych. Obecnie notuje się znaczny spadek notowanych typów pyłku w powietrzu Winnicy. Wykazano, że dzieci są wrażliwe na pyłek roślin zielnych, w tym ambrozji, bylicy i traw, a dorośli są bardziej wrażliwi na pyłek drzew i traw. Dalsze badania spektrum pyłku w powietrzu są niezbędne w celu łagodzenia objawów alergii u osób wrażliwych. 